\title{
Earnings Management, Debt Maturity, Dividend Policy and Future Performance of Manufacturing Companies in Indonesia
}

\author{
Filiana Filiana*, Bandi Bandi \\ Sebelas Maret University, Ir. Sutami Street Number 36A Kentingan, Surakarta, \\ Indonesia \\ *filianalifi206@gmail.com
}

\section{CITATION:}

Filiana, F. \& Bandi, B. (2021).

Earnings Management, Debt Maturity, Dividend Policy and Future Performance of Manufacturing Companies in Indonesia. JIA (Jurnal Ilmiah Akuntansi), 6 (2), 394-412.

\section{ARTICLE HISTORY:}

Received:

July $3^{\text {th }}, 2021$

Revised:

November 15th, 2021

Accepted:

December 22 $2^{\text {th }}, 2021$

DOI:

$10.23887 /$ jia.v6i2.33233

\begin{abstract}
The purpose of this study is to examine the relationship between earnings management, debt maturity, and dividend policy on the future performance of manufacturing companies in the capital market in Indonesia. This study uses manufacturing companies listed on the Indonesian stock exchange in the period 2014 to 2019. Sampling in this study uses a purposive sampling technique. The data analysis method in this study is multiple regression analysis using 192 observational data. The results of this study find that simultaneously earnings management, debt maturity and dividend policy have a significant effect on the company's future performance. Partially, earnings management variables have a negative effect on the company's future performance, and the debt maturity variable has a positive effect on the company's future performance. The dividend policy variable partially has no effect on the company's future performance.
\end{abstract}

Keywords: earnings management, debt maturity, dividends, manufacturing company.

\section{INTRODUCTION}

This study examined the effect of earnings management, debt maturity, and dividend policy on the company's future performance. Company performance is important to measure the success of the business being run. Company performance can reflect the ability of a company in managing its resources. Company performance can be influenced by several factors, including concentrated or not concentrated ownership, earnings manipulation, and disclosure of financial statements. The sustainability of the company is marked by an increase in the value of the company which is reflected in the achievement of the targeted earnings (Prasetyo, Subchan, \& Harjanto, 2017). 
Earnings management is one of the methods used by management in the process of preparing financial statements that can affect the level of earnings displayed. The purpose of earnings management is to improve the welfare of certain parties even though in the long term there is no difference between the company's cumulative earnings and the earnings that can be identified as profit. There are two ways to understand earnings management. First, as management's opportunistic behavior to maximize its utility in the face of compensation, debt contracts, and political costs. Second, looking at earnings management from the perspective of efficient contracts, namely earnings management gives managers the flexibility to protect themselves and the company in anticipating unexpected events for the benefit of all parties involved in the contract (Scott, 2015).

The earnings management case was carried out by the management of the PT Tiga Pilar Sejahtera Food Tbk (AISA) company, on March 29th, 2019 the Indonesia Stock Exchange (IDX) summoned the directors of PT Tiga Pilar Sejahtera Food Tbk (AISA) to request an explanation regarding the release of the results of the financial statement investigation 2017 by PT Ernst \& Young Indonesia (EY). The results of EY's investigation on the financial statements showed that there were findings of an alleged inflated accounting post of IDR 4 trillion by the company's old management. This led to a decrease in the performance of PT Tiga Pilar Sejahtera which was caused by the disclosure of cases of inflated company earnings carried out by the company's management. So that the Financial Services Authority (OJK) continues to monitor the problems that are being faced by PT Tiga Pilar Sejahtera Food Tbk (AISA) related to the results of the investigation on the company's financial statements for the period 2017 which were alleged to be problematic (CNBC Indonesia.com).

Performance improvement was carried out by improving capital. Regarding capital cannot be separated from debt, because the capital of a company is not a few that uses debt as part of it. Debt is a valuable monitoring tool for companies with large cash flows and few growth opportunities as managers commit to disbursing fixed interest payments to debt holders, thereby reducing free cash flow problems. Therefore, a high debt ratio lowers the agency costs of equity financing and thereby increases company profitability by encouraging managers to align their interests with those of shareholders (Vijayakumaran \& Vijayakumaran, 2019). 
When the company has been able to operate smoothly and earn a profit, the next decision the company makes is whether the company will distribute dividends or withhold earnings. Financial managers can decide the best dividend policy and also decide when they will distribute dividends and when to hold earnings, with the right decisions it will increase the value of the company (Pamungkas \& Puspaningsih, 2013).

$$
\text { Prasojo \& Fatayati }
$$
conducted a study on the effect of company performance on earnings management practices and the results of the study stated that company performance affected earnings management practices. Research conducted by Muid (2007) also showed that there was no difference in the operating performance of companies that carried out earnings management with companies that carried out earnings management. Meanwhile, research conducted by Al-Shattarat, Hussainey, \& Al-Shattarat (2018) found that real earnings management had a positive effect on future operating performance. Another study conducted by Li, Abeysekera, \& Ma (2011) found that earnings management performed better than earnings quality in predicting future profitability. This study was inconsistent with $\mathrm{Ma} \& \mathrm{Ma}$ (2017) who found that earnings management was negatively related to company performance. Based on the background described and the findings of previous studies, the researcher was interested and focused on examining the relationship among earnings management, debt maturity, and dividend policy on the future performance of manufacturing companies in Indonesia.

\section{LITERATURE REVIEW AND HYPOTHESES FORMULATION \\ Agency Theory}

Agency theory is the development of a theory that studies a contract design in which agents work or serve on behalf of the principal when the agent's desires or goals conflict, there will be a conflict. The agency conflict caused by income smoothing is triggered by the separation of roles or differences in interests between the principal and the agent. Actually, agency theory has cooperative and noncooperative characteristics. The concept of agency theory according to (Scott, 2015) is a relationship or contract between the principal and the agent, where the principal is the party who employs the agent to perform tasks for the interest of the principal, while the agent is the party who carries out the interests of the principal. The focus of this theory is to determine the most efficient contract to regulate principal- 
agent relationships on assumptions about human behavior such as selfinterest, limits of rationality, risk aversion, conflicts among members within the organization, and information as a commodity that can be purchased (H.DEMTSEZ, 1972).

In the concept of agency theory, management as an agent should prioritize the interests of shareholders, but it does not rule out the possibility that management is only concerned with its own interests to maximize utility. Management can take actions that do not benefit the company as a whole which in the long term can harm the interests of the company. Even to achieve its own interests, management can act using accounting as a tool for engineering. The difference in interests between the principal and the agent is called the agency problem, one of which is caused by the existence of information asymmetry. Agency theory can solve two problems that arise between the agent and the principal (Adams, 1996).

\section{Company Performance}

According to IAI (2007), financial performance is the company's ability to manage and control its resources. Company performance is a certain measure used by companies to assess the company's success in generating profits. Fahmi (2014: 2), said that financial performance is an analysis carried out to see how far a company has implemented using financial implementation rules properly and correctly. Such as by making a financial statement that meets the standards and provisions in SAK (Indonesian Accounting Standards) or GAAP (General Accepted Accounting Principles) and others. A company can be said to be successful if it has achieved the standards and objectives that have been set. The performance of a company can be measured through its financial performance (Pratiwi \& Laksito, 2014).

\section{Earnings Management}

Scott (2015) defined earnings management as the choices made by managers in determining accounting policies and influencing earnings so as to achieve certain goals. Earnings management occurs as a result of agency problems that occur due to misalignment of interests between shareholders (principals) and company management (agents). As agents, managers are morally responsible for optimizing the earnings of shareholders, but on the other hand, managers also have an interest in maximizing their own welfare, so there is a high possibility that agents do not always act in the best interests of the principal (Jensen \& Meckling, 1967). 
According to Healy \& Wahlen (1999) earnings management occurs when management uses a policy in financial reporting and preparation of transactions to change financial statements to influence stakeholders' perceptions of the company's performance or influence contractual results which depend on the reported accounting value.

\section{Debt Maturity}

According to the FASB in Kieso et al. (2014) defined obligations as possible future sacrifices of economic benefits arising from present obligations of a particular entity to transfer productive assets or services to other entities in the future as a result of past transactions or events. It can be concluded that debt is a company's financial obligations to other parties that must be paid with debt, goods, or services at maturity. The maturity level of debt is the deadline for payment of an entity's debt in paying off a number of external loan funds to creditors. Companies must consider debt maturity when choosing debt as a source of funding. This is because the selection of debt maturity will affect the value of the company (Barclay $\&$ Smith, 1995).

\section{Dividend Policy}

A dividend is one form of return that may be obtained by investors in addition to capital gains. As for companies, the dividend is the cost of the source of funds obtained from investors to finance their business activities (Astuty \& Siregar, 2008). The dividend policy is a decision whether the profits earned by the company at the end of the year will be distributed to shareholders in the form of dividends or retained to increase capital for investment financing in the future (Dahayani et al., 2017)

\section{Hypothesis}

The Effect of Earnings Management on Company Performance

According to agency theory, earnings management can cause agency costs that are triggered by the separation of roles or differences in interests between shareholders and company management. Management as the manager of the company has more many and prior information about the company than the shareholders. Therefore, management practices accounting with earnings orientation to achieve a certain performance (Purwanti, 2010). Research conducted by Santoso et al. (2017) on manufacturing companies on the Indonesian stock exchange found that earnings management had a significant 
positive effect on company performance. Positive earnings management indicated that an increase in earnings management caused an increase in company performance in the future period. Meanwhile, research conducted by Prasetyo et al. (2017) found that earnings management had a negative effect on company performance. Based on the theoretical review and various studies above, hypothesis 1 was formulated as follows: $\mathrm{H}_{1}$ : Earnings Management has a negative effect on the future performance of manufacturing companies in Indonesia.

The Effect of Debt Maturity on Company

\section{Performance}

The amount of debt used by the company to finance its activities is a company policy related to the capital structure. This policy is inseparable from the company's efforts to increase the value of the company through increasing the prosperity of the owners and shareholders. Agency theory explains the possibility that the interests of management conflict with the interests of shareholders. Shareholders want the company's funding to be financed by debt, but it is opposed by managers who think that debt is a high risk. Herdiyanto (2015) in his research found that debt structure as measured by the ratio of total debt and long-term ratio had a significant negative effect on company performance. The results of this study were different from the research conducted by Damarjati et al. (2019) which examined the effect of debt maturity on the company's financial performance, and the results of his research found that debt maturity had a positive effect on the company's financial performance. Meanwhile, research conducted by Tere et al. (2014); Warmana \& Widnyana (2020) found that debt had a significant negative effect on company performance, this study was in line with research conducted by Amirya \& Atmini (2008) explaining that debt levels were negatively related to firm value. The level of debt showed a negative direction, meaning that at a low level of debt the value of the company is high. On the other hand, at high debt levels, firm value is low. Based on the theoretical review and various studies above, hypothesis 2 was formulated as follows:

$\mathrm{H}_{2}$ : Debt Maturity has a positive effect on the future performance of manufacturing companies in Indonesia.

The Effect of Dividend Policy on Company Performance

Dividends are part of the company earnings that become the rights of 
shareholders. The distribution of dividends to shareholders will reduce the company's free cash flow which has the potential to be misused for the benefit of managers so that the potential for agency problems between managers and shareholders will decrease. The value of the company can be seen from the company's ability to pay dividends. The ability of a company to pay dividends is closely related to the company's ability to earn profits. If the company earns high profits, then the company's ability to pay dividends is also high. With large dividends, it will increase the firm value (Jariah, 2016). Kamran, Chakir Lamrani, \& Khalid (2019) conducted a study of 40 cement sector companies on the Karachi stock exchange Pakistan finding that dividend policy affected company performance. In Indonesia, research conducted by Jariah (2016) found that dividend policy had no significant effect on firm value. Meanwhile, research was conducted by Damarjati (2019) found that dividend policy did not affect company performance, this result was consistent with previous research conducted by Suherli \& S. Harahap (2007). Based on the theoretical review and various studies above, hypothesis 3 was formulated as follows:

$\mathrm{H}_{3}$ : Dividend policy has a positive effect on the future performance of manufacturing companies in Indonesia.

\section{METHOD}

This research was quantitative research and used descriptive statistical analysis, panel data regression analysis, classical assumption test, $\mathrm{F}$ statistical test, and $\mathrm{t}$ statistic test to test the effect of earnings management, debt maturity, and dividend policy on the company's future performance. The population in this study was manufacturing companies listed on the Indonesian stock exchange with the research period starting from 2014-2019. The sample selection in this study used the purposive sampling method. Tests in this study were carried out using the eviews program.

\section{Independent Variable}

Earnings Management

The earnings management variable in this study used discretionary accruals as a proxy to calculate the value of earnings management using the Modified Jones Model because this model is considered better than other models for measuring earnings management and this model has a standard error from eit (error term) regression results of the smallest total accrual value compared to other 
models. The calculation of the Modified Jones Model is formulated as follows:

Total Accruals (TA), Total Accruals value can be calculated by the formula:

\section{TACCit $=$ NIit - OCFit}

The total accrual value (TAC) estimated by the OLS regression equation is as follows:

TACCit/TAit-1 = a1 (1 / TAit-1) + a2 (DREVit / TAit-1) + a3 (PPEit / TAit-1)

Information:

TACCit is the Total Accrual of $i$ company in year t; Niit is the Net Income of $\mathrm{i}$ company in year $\mathrm{t}$; OCFit is the Operating Cash Flow of i company in year t; TAit- 1 is the Total assets of i company in year t$1 ; \triangle \mathrm{REV}$ it is Change in earnings of $i$ company in year t; PPEit is the value of the company's fixed assets in year $t$.

\section{Non-Discretionary Accruals (NDA)}

By using the regression coefficient above the value of nondiscretionary accruals (NDA) can be calculated by the formula:

NDACCit $=$ a1 $(1 /$ TAit-1 $)+a 2$ (DREVit / TAit-1 - $\triangle$ RECit/ TAit1) + a3 (PPEit/ TAit- 1)

Information:

NDACCit is Non-Discretionary Accruals of $\mathrm{i}$ company in year $\mathrm{t}$; TAit- 1 is the Total assets of $i$ company in year $\mathrm{t}-1 ; \Delta \mathrm{REVit}$ is
Change in earnings of i company in year $\mathrm{t}$; $\triangle \mathrm{RECit}$ is Change in receivables of $i$ company in year $t$; PPEit is the Value of the company's fixed assets in year $t$.

\section{Discretionary Accruals (DA)}

Furthermore, discretionary accruals (DA) can be calculated as follows:

\section{DACCit $=($ TACCit $/$ TAit-1) - NDACCit}

Information:

DACCit is the Discretionary Accruals of i company in year t; NDACCit is Non Discretionary Accruals of $\mathrm{i}$ company in year $\mathrm{t}$; TACCit is the Total accruals of $i$ company in year t; TAit- 1 is the Total assets of $\mathrm{i}$ company in year $\mathrm{t}$ 1.

Debt Maturity

Debt is classified into two, namely current liabilities or also called short-term debt (STD), and non-current liabilities or long-term debt (LTD). The debt used in this study was long term debt (LTD) as measured by the longterm debt ratio. The formula is as follows:

$$
\text { STD }=\frac{\text { Long Term Debt }}{\text { Total Debt }} \times 100 \%
$$

\section{Dividend Policy}

The dividend policy is a decision on whether earnings will be paid as 
dividends or retained for reinvestment in the company. In this study, dividend policy was proxied by the Dividend Payout Ratio (DPR).

$$
\mathrm{DPR}=\frac{\text { Dividend Per Share }}{\text { Earning Per Share }} \times 100 \%
$$

Dependent Variable

The dependent variable in this study was the company's future performance as measured by operating cash flow (CFO).

\section{Control Variable}

The control variable is a constant variable that keeps the effect of the independent variable on the dependent variable not influenced by external factors that are not examined. There were two control variables in this study, namely, firm size, and profitability. Where firm size is the control variable measured by Ln total assets, while profitability is a control variable as measured by the ratio of return on assets.

\section{RESULTS AND DISCUSSION}

This study used secondary data in the form of financial statements from 2014 to 2019. This data was obtained from the website www.idx.co.id. The population in this study was manufacturing companies listed on the Indonesia Stock Exchange. The sampling technique was carried out by purposive sampling, to obtain a sample of 200 companies.

\section{Selection of Regression Estimation Model}

To determine the regression model to be used in the study, three data tests were used. The three data tests were Chow Test, Hausman Test, and Lagrange Multiplier Test. Each of these statistical tests would produce

Table 1. Research Sample

\begin{tabular}{llc}
\hline \multicolumn{1}{c}{ No. } & \multicolumn{1}{c}{ Information } & Total \\
\hline 1. & Manufacturing companies listed on the IDX in 2014-2019. & 200 \\
2. & Manufacturing companies that publish annual reports and complete & $(0)$ \\
& annual financial statements consecutively from 2014-2019. \\
3. & Manufacturing companies that had complete financial data in & $(0)$ \\
& accordance with the measurement of the variables that would be \\
& examined in this research. & \\
& Total research samples & 200 \\
& Outlier & $(8)$ \\
& Total samples after outlier & 192 \\
\hline
\end{tabular}


Table 2. Chow Test

\begin{tabular}{lrrr}
\hline Effects Test & Statistic & d.f. & Prob. \\
\hline Cross-section F & 1.244770 & $(200,658)$ & 0.0242 \\
Cross-section Chi-square & 277.246149 & 200 & 0.0002 \\
\hline
\end{tabular}

Source: Processed secondary data, 2021

Table 3. Hausman Test

\begin{tabular}{lrrr}
\hline Test Summary & Chi-Sq. Statistic & Chi-Sq. d.f. & Prob. \\
\hline Cross-section random & 3.092642 & 5 & 0.6857
\end{tabular}

Source: Processed secondary data, 2021

recommendations for the best method. The method that has the most recommendations would then be chosen as the method for performing panel data regression.

\section{Chow Test}

The first test carried out was the chow test. This test was conducted to determine the regression model and panel data which is better between the common ordinary least square (OLS) model and the fixed effect model (FEM). The results of the chow test are as depicted in Table 2.

Based on the results of the Chow test, if the prob value for cross-section $\mathrm{F}$ is less than 0.05, then the model chosen is the fixed effect, but if the value is more than 0.05 , the model chosen is the common effect. The Chow test above showed that the results of the $\mathrm{F}$ redundant test were significant. It can be seen from prob. Cross-section $F$ of 0.0242 less than
0.05. So based on the results of the Chow test, a more precise estimation model was the fixed effect. Because the chosen one was the fixed effect, then the Hausman test was carried out.

\section{Hausman Test}

This test was conducted to determine which panel data regression model is better between the random effect model (REM) and the fixed effect model (FEM). Table 3 show the Hausman test results. In the Hausman test, if the prob value for cross-section random is less than 0.05, the model chosen is a fixed effect, but if the value is more than 0.05 , the selected model is a random effect. The table above showed the cross-sectional random prob value of 0.6857 which was greater than 0.05 so that the correct regression model was a random effect. Based on the Hausman test, it can be concluded 
that the best regression model used in this study was the random effect model

\section{Classic Assumption Test}

In this study, the classical assumption test has been carried out which showed that the data was normally distributed with a probability value at Jarque-Bera of 0.114046 or greater than $0.05(0.114046>0.05)$. The multicollinearity test showed that the tolerance value was above 0.01 and the VIF was less than 10.00. Thus, it can be concluded that in the regression model there was no multicollinearity problem. In the analysis of the heteroscedasticity test through the glejser test, the probability value of $0.0642>0.05$ can be concluded that there was no heteroscedasticity problem. In the autocorrelation test, it can be seen from the Durbin-Watson table with $k=3 ; a=5 \%$ and $n=866$, $d U$ for the total data was 866 and the total independent variables 3 was 1.88258 so that the 4-dU value was 2.11742 (4-1.88258), it can be concluded that there was no autocorrelation in the regression model.

\section{Hypothesis Testing}

Based on the results of the regression analysis in the Table 4 , it was known that the independent variable, namely earnings management (EM) had a significant value of 0.0000 ; debt maturity had a significant value of 0.0445 ; dividend policy had a significant value of 0.1451 ; and the control variable, namely size, had a significant value of 0.2554; profitability (ROA) had a significant value of 0.9167 .

\section{Simultaneous Test (F Test)}

Based on the results of the regression above, it was known that the value of Prob. (F-Statistic) was $0.0000<0.05$, so the variable of earnings management (EM), debt maturity, dividend policy simultaneously had a significant effect on the future performance of manufacturing companies in Indonesia.

\section{Coefficient of Determination Test $\left(\mathbf{R}^{2}\right)$}

According to Ghozali (2011) the Coefficient of Determination (R2) aims to describe the ability of the model to explain the variations that occur in the dependent variable. The $\left(R^{2}\right)$ value that is close to one means that the independent variables provide almost all the information needed to predict the variation of the dependent variable. The results of the calculation of the coefficient of determination hypothesis test can be seen above. 
Table 4. Regression Test

\begin{tabular}{crrrr}
\hline Variable & Coefficient & Std. Error & t-Statistic & Prob. \\
\hline C & 99519.72 & 23945.15 & 4.156153 & 0.0000 \\
EM & -6568.008 & 866.5573 & -7.579427 & 0.0000 \\
DEBT & 39764.42 & 21481.84 & 1.851072 & 0.0445 \\
DIVIDEND & 133.4648 & 91.50902 & 1.458488 & 0.1451 \\
SIZE & 15.07969 & 13.25071 & 1.138029 & 0.2554 \\
PROF & 80.97723 & 773.7089 & 0.104661 & 0.9167 \\
\hline
\end{tabular}

Effects Specification

\begin{tabular}{llll}
\hline Cross-section random & & \\
\hline & Weighted Statistics & \\
\hline R-squared & 0.067387 & Mean dependent var & 106312.2 \\
Adjusted R-squared & 0.061952 & S.D. dependent var & 149966.3 \\
S.E. of regression & 145201.3 & Sum squared resid & $1.81 \mathrm{E}+13$ \\
F-statistic & 12.39918 & Durbin-Watson stat & 1.887107 \\
Prob(F-statistic) & 0.000000 & & \\
\hline
\end{tabular}

\begin{tabular}{llll}
\hline \multicolumn{4}{c}{ Unweighted Statistics } \\
\hline R-squared & 0.070056 & Mean dependent var & 119977.3 \\
Sum squared resid & $1.92 \mathrm{E}+13$ & Durbin-Watson stat & 1.781164 \\
\hline
\end{tabular}

Source: Processed secondary data, 2021

The value of $R$ Square $\left(R^{2}\right)$ was 0.067 .

This means that $6 \%$ of the CFO dependent variable can be explained by earnings management, debt maturity, and dividend policy.

\section{Partial Test (t-Test)}

Based on the results of the panel data regression analysis in the table above, it was known that the independent variables, namely Earnings management (EM) and Debt maturity had a significant value of
0.0000 ; and $0.0445>0.05$. This means that in this study the earnings management and debt maturity variables affected the future performance of manufacturing companies in Indonesia, while the dividend policy variable had a significant value of $0.1451<0.05$, meaning that the dividend policy variable cannot affect the company's future performance. While the control variable in this study, namely the firm size had a significant value of 0.255 
$<0.05$, meaning that the firm size variable cannot affect the future performance of the company and the control variable, namely profitability as measured by ROA had a significant value of $0.916<0.05$, the profitability variable was not affected on the future performance of the company.

\section{Discussion}

The Effect of Earnings Management on the Company's Future Performance as Measured by Operating Cash Flow (CFO)

Based on the results of hypothesis testing in the regression, the coefficient value was -6568.008 with a significant value of 0.0000 . The significant level of the earnings management variable was smaller than $0.05(0.0000<0.05)$ thus $\mathrm{H}_{1}$ was accepted. This showed that earnings management practices in manufacturing companies in Indonesia had a significant effect on the company's future performance with a negative relationship direction.

This explained that earnings management practices by company management can improve company performance so that when a company practices earnings management, the company will be able to estimate the company's performance in the future. By practicing earnings management, the company can also affect the level of earnings displayed to match what is expected by the company's management.

The results of this study were consistent with research conducted by Purwanti (2010); Nugroho et al. (2015); Prasetyo et al. (2017); and Marfungatun \& Isfaatun (2019) where their research found that earnings management affected company performance with the assumption that the higher the earnings management in a company, the lower the company's performance.

Table 5 Hypothesis Testing Analysis Results

\begin{tabular}{ccccccc}
\hline No. & Variable & Coefficient & Std. Error & t-Statistic & Prob. & Information \\
\hline 1. & $\begin{array}{c}\text { Earnings } \\
\text { management }\end{array}$ & -6568.008 & 866.5573 & -7.579427 & 0.0000 & $\begin{array}{c}\mathrm{H}_{1} \text { was } \\
\text { Accepted }\end{array}$ \\
2. & Debt maturity & 39764.42 & 21481.84 & 1.851072 & 0.0445 & $\mathrm{H}_{2}$ was \\
3. & Dividend policy & 133.4648 & 91.50902 & 1.458488 & 0.1451 & $\begin{array}{c}\mathrm{H}_{3} \text { was } \\
\text { Rejected }\end{array}$ \\
\hline
\end{tabular}

Source: Processed secondary data, 2021 
This study was different from previous research conducted by Santoso et al. (2017) who found that earnings management had no significant positive effect onthe performance of manufacturing companies in Indonesia.

The Effect of Debt Maturity on the Company's Future Performance as Measured by Operating Cash Flow (CFO)

The results of the hypothesis testing of the debt maturity variable obtained a coefficient value of 39764.42 with a significant value of 0.0445. The significant level was smaller than $0.05(0.0445<0.05)$, so $\mathrm{H}_{2}$ was accepted. This showed that debt maturity as measured by the long-term debt ratio had a significant effect on the company's future performance with a positive relationship direction.

The results of this study indicated that when the level of debt maturity is high, the company's performance decreases, whereas when the level of debt maturity is low, the company's performance increases. The addition of debt will improve the company's performance, this is because investors view that if the company increases its debt, the company is able to fulfill its obligations and has good goals in the future. The results of this study also indicated that the maturity level of the company's debt can be used as a reference to estimate the company's performance in the future. This study was consistent with research conducted by Amirya \& Atmini (2008); Tere et al. (2014); Herdiyanto (2015); Damarjati et al. (2019) and Warmana \& Widnyana (2020) who found that debt affected company performance. Different results were found by Sari Dewi \& Mulyani (2020) who found that debt maturity affected the company's financial performance.

The Effect of Dividend Policy on the Company's Future Performance as Measured by Operating Cash Flow (CFO)

Hypothesis testing for the dividend policy variable had a coefficient value of 133.46 with a significant value of 0.145 greater than 0.05 (0.145>0.05), so $\mathrm{H}_{3}$ was rejected. This means that there was no effect of dividend policy on the future performance of manufacturing companies in Indonesia. The results of this study indicated that the ability of a company to pay dividends cannot improve performance, and the various dividend policies implemented by the company cannot be used as a reference for estimating the company's performance in the future. 
This result also showed that the company's performance cannot be seen from the company's ability to pay dividends, because the company's ability to pay dividends is closely related to the company's ability to earn profits. If the company earns high profits, then the company's ability to pay dividends is also high. Large dividends will increase the value of the company. This means that an increase or decrease in a company's dividend policy did not affect the company's performance. This study was consistent with research conducted by Damarjati et al. (2019) and Suherli \& Harahap (2007) who found that dividend policy did not affect company performance. In contrast to research conducted by Resti (2019), this study found that dividend policy had a positive effect on company performance.

\section{CONCLUSION, IMPLICATION, AND LIMITATION}

In the discussion, it can be concluded that the earnings management variable had a significant negative effect on the company's future performance. This indicated that earnings management practices carried out by the company's management can provide influence on the future performance of manufacturing companies in
Indonesia. The debt maturity variable had a significant positive effect on the company's future performance. This showed that the greater the debt maturity, the lower the level of the company's performance, on the contrary, the smaller the debt maturity, the higher the level of the company's performance. The dividend policy variable had no significant effect on the company's future performance. This indicated that the dividend policy in a company cannot change or affect the level of company performance. The control variables, namely firm size and profitability (ROA), found that the size and profitability variables did not affect the company's future performance.

It is expected that the conclusions of this study can provide new insights on earnings management, debt maturity, and dividend policy with their relationship to the company's future performance. This research can be an inspiration for further researchers to investigate further regarding earnings management, debt maturity, and dividend policy on company performance. In addition, this study also had several limitations, using only 3 independent variables, earnings management, debt maturity, and dividend policy, which were considered insufficient to determine 
the factors that affected the performance of manufacturing companies in Indonesia. This research was also limited to manufacturing companies listed on the Indonesian stock exchange. This opens up opportunities for further research by expanding observations. Based on the limitations that have been described previously, further research is recommended to add research variables to make it easier to find out what factors can affect company performance such as good corporate governance, audit quality, ownership structure, and others.

\section{REFERENCES}

Adams, J. (1996). 1. Principals and Agents , Colonialists and Company Men: American Sociological Review1, 61(1), 1228.

Al-Shattarat, B., Hussainey, K., \& AlShattarat, W. (2018). The impact of abnormal real earnings management to meet earnings benchmarks on future operating performance. International Review of Financial Analysis. https://doi.org/10.1016/j.irfa.20 18.10.001

Amirya, M., \& Atmini, S. (2008). Determinan Tingkat Hutang Serta Hubungan Tingkat Hutang Terhadap Nilai Perusahaan: Perspektif Pecking Order Theory. Jurnal Akuntansi Dan Keuangan Indonesia, 5(2), 227-244. https://doi.org/10.21002/jaki.20 08.11

Astuty, N. M. R. K., \& Siregar, S. V.
(2008). Hubungan Antara Sinyal Dividen Tunai Dengan Kinerja Operasional Dan Kinerja Pasar. Jurnal Akuntansi Dan Keuangan Indonesia, 5(1), 77-101.

Azzahra, A. S., \& Nasib. (2019). Pengaruh Firm Size Dan Leverage Ratio Terhadap Kinerja Keuangan pada Perusahaan Pertambangan. Jwem Stie Mikroskil, 9(1), 13-20.

Barclay, M. J., \& Smith, C. W. (1995). The Maturity Structure of Corporate Debt. The Journal of Finance, 50(2), 609-631.

Dahayani, N. K. S., I Ketut Budiartha, B., \& Suardikha, I. M. (2017). Pengaruh Kebijakan Dividen Pada Manajemen Laba Dengan Good Corporate Governance Sebagai Moderasi. E-Jurnal Ekonomi Dan Bisnis Universitas Udayana, 6(4), 1395-1424.

Damarjati, A., Akuntansi, D., Ekonomika, F., Diponegoro, U., Prof, J., \& Sh, S. (2019). Pengaruh Leverage, Debt Maturity, Kebijakan Dividen, Dan Cash Holdings Terhadap Kinerja Keuangan Perusahaan (Studi Pada Perusahaan Manufaktur Yang Terdaftar Di Bei Tahun 2017). Diponegoro Journal of Accounting, 7(4), 1-12.

Erawati, T., \& Wahyuni, F. (2019). Pengaruh Corporate Governance, Ukuran Perusahaan, Dan Leverage Terhadap Kinerja Keuangan Perusahaan Di Bursa Efek Indonesial Studi Kasus Perusahaan Manufaktur Yang Terdaftar di Bursa Efek Indonesia Periode 2013-2017 ). Jurnal Akuntansi Pajak Dewantara, 1(2), 129-137.

Fahmi, Irham.( 2014). Analisis Kinerja Keuangan, Alfabeta. Bandung.

Healy, P. M., \& Wahlen, J. M. (1999). 
A review of the earnings management literature and its implications for standard setting. Accounting Horizons, 13(4), 365383.

https://doi.org/10.2308/acch. 19 99.13.4.365

Herdiyanto, W. S. (2015). Pengaruh Struktur Utang Terhadap Kinerja Perusahaan (Studi Empiris Pada Perusahaan Manufaktur Tahun 2011-2013). Diponegoro Journal of Accounting, 4(3), 531-540.

Ifada, L. M., \& Inayah, N. (2017). Analisis Pengaruh Tingkat Leverage Terhadap Kinerja Perusahaan (Studi Pada Perusahaan Food and Beverage Yang Terdaftar di BEI Tahun 2011-2013). Fokus Ekonomi, 12(1), 19-36. http://ejournal.stiepena.ac.id/in dex.php/fe/article/view/160

Isbanah, Y. (2015). Pengaruh Esop, Leverage, and Ukuran Perusahaan Terhadap Kinerja Keuangan Perusahaan Di Bursa Efek Indonesia. Jurnal Riset Ekonomi Dan Manajemen, 15(1), 28.

https://doi.org/10.17970/jrem.1 5.150103 .

Jariah, A. (2016). Likuiditas, Leverage, Profitabilitas

Pengaruhnyaterhadap Nilai Perusahaan Manufaktur Di Indonesia Melalui Kebijakan Deviden. Riset Akuntansi Dan Keuangan Indonesia, 1(2), 108118.

https: / / doi.org/10.23917/ reaksi. v1i2.2727

Jensen, M. C., \& Meckling, W. H. (1967). Theory of the firm: managerial behavior, agency costs and ownership structure. Journal of Financial Economics, 3(February 2012), 305-360.
Kamran, K., Chakir Lamrani, H. C., \& Khalid, S. (2019). The impact of dividend policy on firm performance: A case study of the industrial sector. Risk Governance and Control: Financial Markets and Institutions, 9(3), 23-31.

Kieso, D. E., Weygandt, J. J., \& Warfield, T. D. (2014). Accounting Intermediate.

Li, F., Abeysekera, I., \& Ma, S. (2011). Earnings management and the effect of earnings quality in relation to stress level and bankruptcy level of Chinese listed firms. Corporate Ownership and Control, 9(1 D), 366-391.

Ma, S., \& Ma, L. (2017). The association of earnings quality with corporate performance. Pacific Accounting Review, 29(3), 397-422.

Muid, D. (2007). Pengaruh Manajemen Laba Terhadap Kinerja Operasi, Return Saham Pada Perusahaan Publik di Bursa Efek Jakarta(BEJ). 1996, 175-198.

Nugroho, F. A., Fakultas, A., Universitas, E., Jaya, A., Ratnaningsih, D., Fakultas, D., Universitas, E., \& Jaya, A. (2015). Pengaruh Real Earning Management Terhadap Arus Kas Operasi Perusahaan Dengan Kualitas Audit Sebagai Variabel Moderasi ( Studi pada Perusahaan Manufaktur yang Terdaftar. 27(1), 65-76.

Pamungkas, H. S., \& Puspaningsih, A. (2013). Pengaruh keputusan investasi, keputusan pendanaan, kebijakan dividen dan ukuran perusahaan terhadap nilai perusahaan. Jurnal Akuntansi \& Auditing Indonesia, 17(2), 155164.

Prasetyo, W. S., Subehan, \& Harjanto, 
S. (2017). Pengaruh Manajemen Laba Terhadap Kinerja Perusahaan Dengan Good Corporate Governance Sebagai Variabel Moderasi. Jurnal Ekonomi Manajemen Dan Akuntansi, 24(43), 33-48.

Prasojo, P., \& Fatayati, I. R. (2018). Pengaruh Kinerja Perusahaan Terhadap Praktik Manajemen Laba pada Emiten Indeks Saham Syariah Indonesia. Akuntabilitas, 11(1), 183-202.

Pratiwi, T. R., \& Laksito, H. (2014). Perubahan Struktur Dewan Komisaris. Dipnegoro Journal of Accounting, 03(03), 1-8.

Priatna, H. (2016). Pengukuran Kinerja Perusahaan Dengan Rasio Profitabilitas. Jurnal Ilmiah Akuntansi, 7(2), 44-53.

Purwanti, L. (2010). Kecakapan Managerial, Skema Bonus, Manajemen Laba, dan Kinerja Perusahaan. In Jurnal Aplikasi Manajemen (Vol. 8, Issue 2, pp. 430-436).

Santoso, A., Puspitasari, D., \& Widyaswati, R. (2017). Pengaruh Manajemen Laba Dan Ukuran Perusahaan Terhadap Kinerja Perusahaan Dengan Kualitas Audit Sebagai Variabel Pemoderasi (Studi Pada Perusahaan Manufaktur YangTerdaftar di BEI Periode 2011-2014). Jurnal Administrasi Dan Bisnis, 11(Vol.11, No.1, Juli 2017), 71-84.

Scott, W. R. (2015). Financial Accounting Theory. Seventh Edition. Pearson Prentice Hall: Toronto.

Setiawan, N. B. (2013). Analisis Pengaruh Rasio Profitabilitas Terhadap Kinerja Keuangan ( Studi Kasus pada PD . BPR BKK KARANGMALANG ) PROGRAM
STUDI MANAJEMEN. Jurnal.

Suherli, M., \& S. Harahap, S. (2007). Studi Empiris Terhadap Faktor Penentu Kebijakan Jumlah Dividen. In Media Riset Akuntansi, Auditing dan Informasi (Vol. 4, Issue 3, p. 223). https://doi.org/10.25105/mraai. v4i3.1806

Tambunan, J. T. A., \& Prabawani, B. (2018). Pengaruh Ukuran Perusahaan, Leverage Dan Struktur Modal Terhadap Kinerja Keuangan Perusahaan (Studi Pada Perusahaan Manufaktur Sektor Aneka Industri Tahun 2012-2016). Diponegoro Journal of Social And Politic, 1-10. http:/ / ejournals1.undip.ac.id/index.php

Tere, K., Salim, U., \& Djawahir, A. H. (2014). Pengaruh Ukuran Asset, Piutang, Utang, Modal Sendiri, dan Anggota terhadap Kinerja Keuangan dan Kebijakan SHU (Studi pada Koperasi Kredit Anggota Puskopdit Flores Mandiri). Jurnal Aplikasi Manajemen (JAM), Vol. 12(No. 4), h. 594-661.

Vijayakumaran, R., \& Vijayakumaran, S. (2019). Leverage, debt maturity and corporate performance: Evidence from Chinese listed companies. Asian Economic and Financial Review, 9(4), 491-506. https://doi.org/10.18488/journa 1.aefr.2019.94.491.506

Warmana, G. O., \& Widnyana, I. W. (2020). Pengaruh Keputusan Pendanaan Terhadap Kinerja Keuangan Perusahaan Pada Sektor Pariwisata, Restoran Dan Hotel. 12(2), 163-170.

Widarsono, A., \& Hadiyanti, C. P. (2015). Pengaruh Profitabilitas, Leverage Dan Likuiditas Terhadap Kinerja Lingkungan 
JIA (Jurnal Ilmiah Akuntansi) • 6 (2), 394-412• December 2021

(Studi pada Badan Usaha Milik

Negara (BUMN) Sektor

Manufaktur Periode 2009-2013).

Jurnal Riset Akuntansi Dan

Keuangan, 3(3), 837-852.

www.menlh.go.id 